\title{
A DNS-metiláció szerepe és megváltozása az öregedés és a daganatos betegségek kialakulása során
}

\author{
Szigeti Krisztina Andrea ${ }^{1}$ - Galamb Orsolya dr. ${ }^{2}$ - Kalmár Alexandra dr. ${ }^{1}$ \\ Barták Barbara Kinga $^{1}$. Nagy Zsófia Brigitta ${ }^{1}$. Márkus Eszter ${ }^{1}$ \\ Igaz Péter dr. ${ }^{1,2}$. Tulassay Zsolt dr. ${ }^{2}$ - Molnár Béla dr. ${ }^{2}$
}

${ }^{1}$ Semmelweis Egyetem, Általános Orvostudományi Kar, II. Belgyógyászati Klinika, Budapest ${ }^{2}$ Magyar Tudományos Akadémia, Molekuláris Medicina Kutatócsoport, Budapest

\begin{abstract}
Napjainkban a genetikai kutatások mellett egyre inkább előtérbe kerülnek az epigenetikai vizsgálatok, ugyanis az epigenetikai jelenségek - köztük a DNS-metiláció is - részt vesznek a fenotípust meghatározó gének expressziójának szabályozásában, így számos betegség mechanizmusával összefüggenek.

Jelen összefoglaló közleményünk célja az epigenetikai mechanizmusok közül a DNS-metiláció evolúció során történő megjelenésének, funkciói változatosságának, illetve az öregedésben és a rákos megbetegedésekben betöltött szerepének bemutatása.

A DNS-metiláció a prokarióták, az eukarióták, illetve a vírusok körében is megfigyelhető epigenetikai módosulás. A prokarióták és vírusok esetén idegen DNS-sel szembeni védelmi funkciót lát el. A DNS-metiláció prokariótáknál jelentôs szereppel bír a transzkripció regulációjában, a replikáció iniciációjában, illetve a Dam-irányított hibajavításban. A vírusoknál a védelmi funkció mellett a terjedésükhöz szükséges kapszid formálásában is részt vesz. Az eukarióták esetén a DNS-metiláció szerepet játszik a kromatinstruktúra és a transzkripció szabályozásában, a rekombinációban, a replikációban, az X-kromoszóma inaktivációjában, a transzpozonok szabályozásában és az imprinting jelenség létrehozásában. A fenti tulajdonságok mellett evolúciós szereppel is rendelkezik azáltal, hogy megváltoztatja a DNS mutációs rátáját.

Az öregedés során és a rákos megbetegedésekben kialakuló globális hipometilációs eltérések genetikai instabilitáshoz és spontán mutációs eltérésekhez vezethetnek a transzpozonok szabályozásában betöltött funkciójuk révén. A lokális hipermetilációs (például az SFRP1, az SFRP2, a DKK1 és az APC promóterének hipermetilációja) változásoknak a fehérjeexpressziós változások létrehozásában, ezáltal a rák fenotípus kialakulásában van jelentős szerepe. Az elváltozások általános jellege alapján a fenti eredmények a biológiai kor és a betegségek epigenetikai változások kimutatásán alapuló diagnosztikai és prognosztikai módszerei kutatásának fontosságát támasztják alá.
\end{abstract}

Orv Hetil. 2018; 159(1): 3-15.

Kulcsszavak: epigenomika, DNS-metiláció, 5-metilcitozin, öregedés, daganatos megbetegedések

\section{Role and alterations of DNA methylation during the aging and cancer}

Besides the genetic research, increasing number of scientific studies focus on epigenetic phenomena - such as DNA methylation - regulating the expression of genes behind the phenotype, thus can be related to the pathomechanism of several diseases. In this review, we aim to summarize the current knowledge about the evolutionary appearance and functional diversity of DNA methylation as one of the epigenetic mechanisms and to demonstrate its role in aging and cancerous diseases.

DNA methylation is also characteristic/also appear to prokaryotes, eukaryotes and viruses. In prokaryotes and viruses, it provides defence mechanisms against extragenous DNA. DNA methylation in prokaryotes plays a significant role in the regulation of transcription, the initiation of replication and in Dam-directed mismatch repair. In viruses, it participates not only in defence mechanisms, but in the assembly of capsids as well which is necessary for spreading. In eukaryotes, DNA methylation is involved in recombination, replication, $\mathrm{X}$ chromosome inactivation, transposon 
control, regulation of chromatin structure and transcription, and it also contributes to the imprinting phenomenon. Besides the above-mentioned aspects, DNA methylation also has an evolutionary role as it can change DNA mutation rate.

Global hypomethylation appearing during aging and in cancerous diseases can lead to genetic instablility and spontaneous mutations through its role in the regulation of transposable elements. Local hypermethylated alterations such as hypermethylation of SFRP1, SFRP2, DKKI and APC gene promoters can cause protein expression changes, thus contribute to development of cancer phenotype. DNA methylation alterations during aging in cancerous diseases support the importance of epigenetic research focusing on disease diagnostics and prognostics.

Keywords: epigenomics, DNA methylation, 5-methylcytosine, aging, neoplasm

Szigeti KA, Galamb O, Kalmár A, Barták BK, Nagy ZsB, Márkus E, Igaz P, Tulassay Zs, Molnár B. [Role and alterations of DNA methylation during the aging and cancer]. Orv Hetil. 2018; 159(1): 3-15.

(Beérkezett: 2017. szeptember 6.; elfogadva: 2017. szeptember 28.)

Semmelweis Ignácz születésének 200. évfordulóján a Szerkesztőség felkérésére készített tanulmány.

\section{Rövidítések}

$5 \mathrm{caC}=5$-karboxicitozin; $5 \mathrm{fC}=5$-formilcitozin; $5 \mathrm{hmC}=$ 5 -hidroximetilcitozin; $5 \mathrm{hmU}=5$-hidroximetiluracil; $5 \mathrm{mC}=$ 5-metilcitozin; AID/APOBEC = aktivitás-indukált dezamináz/apolipoprotein B mRNS-módosító enzim, katalitikus polipeptidszerú; APC $=$ adenomatosus polyposis coli; $\mathrm{APOBEC1}$ = apolipoprotein $\mathrm{B}$ mRNS-módosító enzim, katalitikus polipeptidszerü 1 ; APOBEC3 = apolipoprotein B mRNS-módosító enzim, katalitikus polipeptidszerű 3 ; ASP = aszpartoaciláz; BER = báziskivágásos hibajavítás; CDKN2A/P16 = ciklin-függő kináz inhibitor 2A; CEBPA = CCAAT/enhanszer kötőfehérje $\mathrm{A}$; CoRep = transzkripciós korepresszorok; CXCL2 = kemokin (C-X-C motívum) ligandum 2; DAM = DNS adeninmetiláz; DKKl = Dickkopf fehérje 1; DNMTl = DNS $($ citozin-5)-metiltranszferáz 1; DNMT3A = DNS (citozin-5)-metiltranszferáz 3A; DNMT3B = DNS (citozin-5)-metiltranszferáz 3B; ecCEBP = extra-coding CEBPA; EZH2 = Zeste homológ enhanszer 2; gbM = géntest-metiláció; GSTP1 = glutation-Stranszferáz $\mathrm{Pl}$; HDAC $=$ hiszton-deacetiláz; HERV = humán endogén retrovírus; hmC $=5$-hidroximetilcitozin; lncRNS $=$ hosszú nem-kódoló RNS; IRF8 = interferon regulációs faktor 8 ; ITGA2B = integrin alegység alfa $2 \mathrm{~B}$; ITGA4 = integrin alegység alfa 4; LINE = hosszú közbeiktatott szakasz; LTR = hosszú terminális ismétlődések; MeCP2 = metil-CpG-kötő fehérje 2; MGMT = O-6-metilguanin-DNS metiltranszferáz; MMR = mismatch repair, DNS-hibajavítási mechanizmus; MT = metiltranszferáz; NGFR = idegi növekedési faktor receptor; PDE4C = foszfodiészteráz 4C; PGR = progeszteronreceptor; piRNS $=$ PIWI-asszociált RNS; PIWI-fehérje $=$ P-elem-indukált wimpy testis fehérje; PRIMAl = prolin-gazdag membrán horgony $1 ; \mathrm{RE}=$ restrikciós endonukleáz; $\mathrm{RM}=$ restrikciósmodifikációs rendszer; RUNX3 = Runt-rokon transzkripciós faktor 3; SDC2 = szindekán-2; SEPT9 = septin 9; SFRPl = szekretált frizzled-rokon fehérje 1; SFRP2 = szekretált frizzledrokon fehérje 2; SFRP5 = szekretált frizzled-rokon fehérje 5; SINE = rövid közbeiktatott szakasz; SNP = egypontos nukleotid-polimorfizmus; SVA elemek $=$ SINE/VNTR/Alu elemek; TDG = timin-DNS glikoziláz; TET = TET metilcitozin dioxigenáz; TF = transzkripciós faktor; TIMP3 = metalloproteináz 3 szöveti inhibitora; TMEFF2 = transzmembrán fehérje EGFszerü és két follisztatinszerü doménnel 2
Napjainkban a genetikai kutatások mellett egyre inkább elôtérbe kerülnek az epigenetikai vizsgálatok, ugyanis az epigenetikai jelenségek - köztük a DNS-metiláció is részt vesznek a fenotípust meghatározó gének expressziójának szabályozásában, így számos betegség mechanizmusával összefüggenek [1]. Az epigenetikai kutatások - amellett, hogy eredményeik segítségével pontosabban megérthetővé válnak az öregedésben és számos betegség kialakulásában közrejátszó molekuláris mechanizmusok - új biomarkerek és terápiás célpont molekulák azonosítását is eredményezik.

Jelen összefoglaló közleményünkben az epigenetikai mechanizmusok közül a DNS-metiláció szerepét, az evolúció során történő megjelenését és funkcióinak változását, a DNS-metiláció szabályozását kívánjuk részletesen bemutatni, valamint összefoglaljuk legfontosabb változásait az öregedés során és a tumoros megbetegedésekben. A DNS-metiláció genetikai instabilitásra és mutációkra gyakorolt hatásáról született legfrissebb tudományos felfedezéseket is ismertetni szeretnénk.

\section{A DNS-metiláció fogalma}

Rana és mtsai feltételezései szerint a DNS-metilációt RNS-metiláció előzte meg a kezdetleges életformák evolúciója során [2]. A korai RNS-világban a katalitikus RNS-ek által végzett RNS-metiláció védelmet jelentett a hidrolitikus emésztődéssel szemben [2]. Késôbb a fenti katalitikus RNS-ek funkcióját felváltották a metiltranszferáz enzimek [2], amelyek egyes típusai RNS- és DNSspecificitással egyaránt rendelkeznek [2]. Rana és mtsai ez utóbbi tulajdonságot fontosnak vélik a DNS-metiltranszferázok, így a DNS-metiláció kialakulásában [2].

A DNS-metiláció a prokarióták, az eukarióták és a vírusok körében is megfigyelhető epigenetikai módosulás $[3,4]$, amely 6-metiladenin, 4-metilcitozin és 5-metilcitozin formájában fordul elő leggyakrabban [3]. A fenti 
posztreplikatív módon létrejövő metilált bázismódosulatok metiltranszferáz enzimek által katalizált kovalens módosítások $[3,4]$.

Bacteria- és Archaea-csoportok esetén a 6-metiladenin, a 4-metilcitozin és az 5-metilcitozin forma egyaránt megjelenik, míg az eukarióták esetén csak a 6-metiladenint és az 5-metilcitozint figyelhetjük meg [3,4] (1. ábra).

\section{A DNS-metiláció funkciója prokariótákban és vírusokban}

A prokarióták körében a metilációt végző metiltranszferáz enzimek többségében az úgynevezett restrikciós-modifikációs rendszer (RM) tagjai [5]. A restrikciós-modifikációs rendszer a prokarióták idegen DNS-sel szembeni védelmi rendszerének a komponense [4]. A rendszert kétféle enzimtípus építi fel: a restrikciós endonukleázok (RE) és az ugyanolyan DNS-szekvenciát felismerő metiltranszferázok (MT) [4]. A restrikciós endonukleázok a felismerő helyüknek megfelelő pontokon hasítják a vírusból származó vagy egyéb idegen DNS-t [4]. Ezek a felismerendő szekvenciák a gazdasejt saját genomjában is megtalálhatók, így ebból adódik a metiltranszferázok funkciója, ami a saját örökítőanyag védelme, méghozzá metiláció által azon szekvenciák mentén, amelyek megegyeznek a restrikciós endonukleázok felismeróhelyével [4].

A nagy jelentőségú restrikciós-modifikációs rendszertől független metiltranszferázok is jelen vannak a prokarióta sejtben [4]. A megfelelő restrikciós endonukleáz pár nélküli metiltranszferáz enzimek, az úgynevezett „árva” metiltranszferázok részt vesznek különböző szabályozó folyamatokban, például DNS-replikáció során [4]. Úgy vélik, hogy a fent említett enzimek szintén a restrikciós modifikációs rendszer tagjai voltak korábban [5].

A DNS-metiláció a prokarióták és a vírusok körében is sokféle funkcióval bír. A Gammaproteobacteria csoportra jellemző Dam metiláz célszekvenciája a GATC, és az enzim legfőbb funkciói közé tartozik a transzkripció regulációja, a replikáció iniciációja, illetve a Dam-irányított hibajavítás [3]. A DNS-replikáció iniciációjának első lépése a DnaA fehérje kötése a DNS origó régiójához. Mind a DnaA fehérjét kódoló DNS-szakasz promótere, mind az origó sok GATC szekvenciával rendelkezik, aminek következményeképpen erősen metilálhatók, illetve kötőfelületként szolgálnak a SeqA fehérjének [3]. A SeqA fehérje hemimetilált formában tartja ezeket a DNS-szakaszokat, így megakadályozva azt, hogy a genom replikálódása egy sejtciklus alatt többször is megtörténjen, ugyanis a replikáció iniciációjának elkezdéséhez az origó és a DnaA promóterének teljes metilációja szükséges [3].

Az imént említett példának is megfelelően a GATC régiók jelenléte a promóter, illetve regulációs szekvenciákban teszi lehetővé a transzkripció szabályozását [3].
Metilált, hemimetilált, illetve metilálatlan formáik szabályozhatják az RNS-polimerázok, illetve a transzkripciós faktorok kötődését [3], például a DnaA esetén a fehérje expressziója csak akkor maximális, ha a promóter szakasz teljesen metilált [3].

A Dam-irányított hibajavítás során a DNS-metiláció szerepe a szülői szál megjelölése, így annak a szálnak a megkülönböztetése a hibajavító rendszer számára, ami alapján a replikáció során létrejött mutációkat javítani kell [3]. A Dam enzim a replikációs villa mögötti hemimetilált kettős spirál frissen szintetizált, metilálatlan szálát metilálja [3]. A DNS-metiláció előtt történik az esetleges mutációk helyreállítása. A spontán mutációk számának növekedését tapasztalták a Dam enzim hiánya és fokozott expressziója esetén egyaránt [3]. Hiánya esetén a soron következő replikációnál a szülői szál nem jelölődik meg, túltermeléskor pedig túl hamar bekövetkezik az új DNS-szál metilációja, így szintén nem jöhet létre a két DNS-szál helyes megkülönböztetése, a mutációk megfelelő templát szerinti kijavítása.

A 6-metiladenozin szerepét bakteriofágok esetén is megfigyelték [6]. Funkciói közé tartozik például, hogy védelmet jelent a fertőzendő baktériummal szemben; restrikciós-modifikációs rendszere hasítani próbálja a vírus örökítő anyagát [6]. Például $M u$ fág esetén a Dam enzim által szabályozott mom gén terméke egy olyan adeninmódosulatot (N6-karboxi-metil-adenin) hoz létre, amely védelmet jelent a baktérium RM-rendszerével szemben [6].

A védelmi funkción kívül szerepet játszik továbbá például Pl fág esetén a kapszid készítésekor az úgynevezett headful DNS-csomagolási mechanizmusban [6]. Ez a mechanizmus konkatemer DNS-molekulákat csomagol a kapszidba [6]. A metiláció e konkatemer DNS-molekulák létrejöttét teszi lehetővé azáltal, hogy a konkatemer DNS kettős spirált hasító enzim csak akkor képes emészteni az örökítő anyagot, ha az a hasító szekvenciákon a legtöbb ponton metilált [7].

\section{A DNS-metiláció funkciója eukariótákban}

Az eukariótáknál alapvetően kétféle metilált bázismódosulat fordul elő: a 6-metiladenozin és az 5-metilcitozin [4]. Az 5-metilcitozin módosulat fóként a CpG-dinukleotidokra jellemző [8]. A CpG-dinukleotidok globálisan nem gyakoriak, viszont bizonyos genomrégiókban, az úgynevezett $\mathrm{CpG}$-szigetek területén igen nagy számban fordulnak elő [8]. A CpG-szigetek általában gének promóter szakaszában, illetve különböző regulátor régióiban találhatók [8] és többségében védettek a DNS-metilációval szemben [9]. A fejlődés során bizonyos promóter régiókban elhelyezkedő $\mathrm{CpG}$-szigetek metilálttá válnak, így az általuk szabályozott gének nem fejeződnek ki [9] (2. ábra) $[10,11]$.

A promóter-metilációt megfigyelhetjük például az Xkromoszóma inaktivációja [12] vagy az imprinting jelensége esetén [13], illetve öregedés során is [9]. A CpG- 


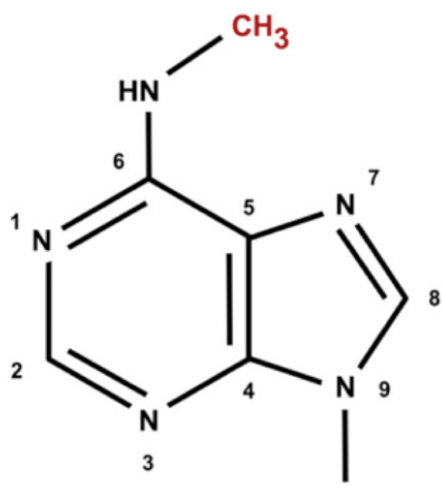

6-metiladenin

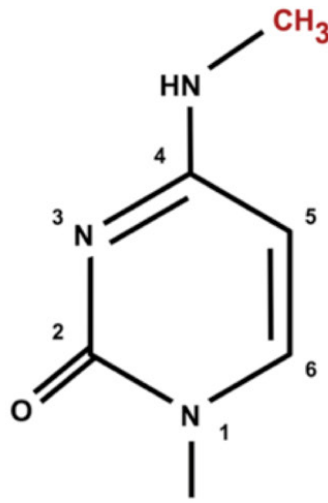

4-metilcitozin<smiles>Cc1cn(C)c(=O)nc1N</smiles>

5-metilcitozin

1. ábra $\quad$ Az élővilágban leggyakrabban előforduló metilált bázismódosulatok

A

Nem metilált DNS

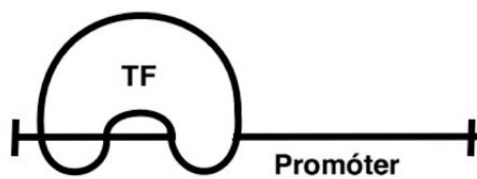

Promóter

Géntest

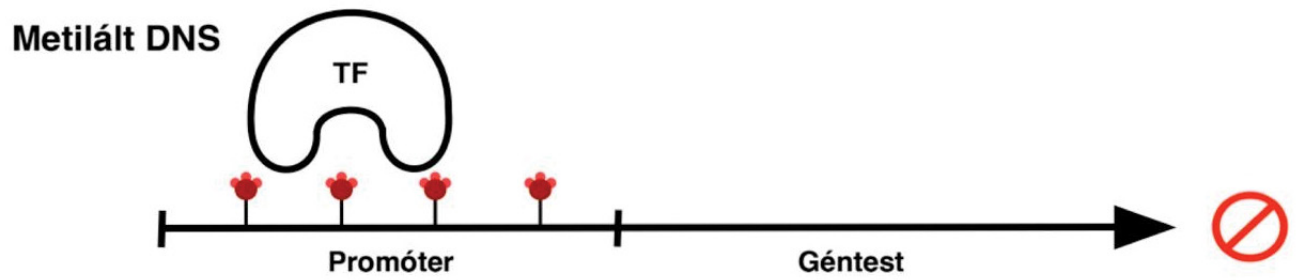

B

Metilált DNS

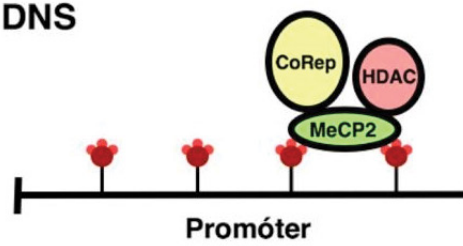

2. ábra

A promóter szakasz DNS-metilációjának hatásai a génexpresszióra. A: A promóter szakaszokon a DNS-metiláció alacsony mértéke vagy teljes hiánya lehetővé teszi a gén átírását, azáltal, hogy nem gátlódik a transzkripciós faktorok kötődése. A promóter szakaszok magas DNS-metilációs szintje viszont megakadályozza a transzkripciós faktorok (TF) kötődését, ezáltal a gén kifejeződését. B: A promóter szakasz DNS-metilációja úgynevezett metil-CpG-kötő fehérjék kötődését teszi lehetővé. Ezekhez a fehérjékhez további fehérjék képesek kapcsolódni, mint például a hiszton-deacetiláz (HDAC), vagy a transzkripciós korepresszorok (CoRep), amelyek a kromatin struktúra megváltozását, a gén inaktiválódását idézik elő [10]

CoRep $=$ transzkripciós korepresszorok; $\mathrm{HDAC}=$ hiszton-deacetiláz; $\mathrm{MeCP} 2=$ metil-CpG-kötő fehérje 2 ; TF $=$ transzkripciós faktor

Az ábra forrása: Ling és mtsai [11] alapján, újraszerkesztve

szigeteken kívüli CpG-dinukleotidok általában az intergenikus régiókban, vagy a gének intronjaiban, így akár repetitív elemekben, transzpozonokban helyezkednek el [8]. A különböző humán szövetek egészséges testi sejtjeiben a CpG-dinukleotidok mintegy 70-90\%-a metilált, amely megközelítőleg a teljes genom $0,75-1 \%$ át teszi ki [8].
A DNS-metiláció szerepet játszik a kromatin struktúra szabályozásában, a transzkripció szabályozásában, a rekombinációban, a replikációban, az X-kromoszóma inaktivációjában, a transzpozonok szabályozásában és az imprinting jelenség létrehozásában $[14,15]$. A fentieken kívül Dixon és mtsai szerint megváltoztatja az adott DNS mutációs rátáját is [16], amely az 5-metilcitozin hiper- 
mutabilitásából fakad, ugyanis ez a metilált bázismódosulás sokkal könnyebben dezaminálódik, mint a citozin, így legtöbbször timinné, mint inkább uracillá alakul [16]. Ez az evolúciót befolyásoló hatás mind a gerincesek, mind gerinctelenek esetén megfigyelhető [16, 17]. Az emlősök esetén genomszerte jelen van, míg gerincteleneknél egyenetlen, elsősorban a gén kódoló szakaszában (gene body methylation: gbM), leginkább exonok területén elhelyezkedő CpG-nukleotidokban előforduló epigenetikai módosítás [15, 17]. Dixon és mtsai agancskorallok vizsgálata során [16] kimutatták, hogy a DNSmetiláció mértéke a konstitutívan, széles körben expreszszálódó fehérjék esetén erősebb, mint szövet-, fejlődési stádium- vagy környezet-specifikusan kifejeződő fehérjék génjeiben. Hasonló megfigyelések születtek növények, korallok, puhatestüek és az ember esetén is, amely alapján Dixon és mtsai a DNS-metiláció fenti, transzkripcióra gyakorolt hatását az evolúció során konzerváltnak tekintik [16].

A gerincteleneknél nem teljeskörüen figyelhető meg a gbM, bizonyos gerinctelen csoportok esetén igen ritka, vagy akár teljesen eltúnhet [16]. Ilyen fajok például az iparban, illetve a kutatásban széleskörüen alkalmazott Saccharomyces cerevisiae vagy a Saccharomyces pombe, amelyek DNS-ében egyáltalán nem fordul elő 5-metilcitozin-módosulás [18]. A Drosophila melanogaster DNSállománya is nagyon alacsony százalékban mutat metiláltságot [18]. Caenorbabditis elegans esetén szintén hiányzik az 5-metilcitozin [19].

A gbM, ahogy bizonyos gerinctelenek esetén, a növények és az emlősök körében is megfigyelhető [15]. Az eukarióták között a növények esetén tapasztaltak legnagyobb mértékű metilációt, ahol akár a genomban található citozinok 50\%-a rendelkezhet e kovalens módosítással [20]. Ez például a kukorica esetén a nagy mennyiségú transzpozon csendesítéséból fakad [21].

A modell növény Arabidopsis thaliana esetén vizsgált gbM fokozta az érintett gén transzkripcióját mind a teljesen metilálatlan génnel szemben, mind a promóter metilációjával ellentétben, amely a transzkripció csendesítését okozza [20]. A transzkripció erôsségének szempontjából a DNS-metiláltság mértéke is meghatározó. Többféle növényi szövet esetén is bebizonyították, hogy a legerősebb és a leggyengébb szintü transzkripció is alacsony DNS-metilációs szint esetén jelenik meg [22]. A gén első két kilobázis hosszú szakaszának, illetve az utolsó egy kilobázis hosszú szakaszának metiláltsága gátolja/visszaveti a transzkripciót [22]. Ennek megfelelően a fenti jelenség a három kilobázisnál rövidebb hosszúságú géneket nagyobb mértékben érinti, amit az Arabidopsis thaliana 2400 metilált génjének esetén ki is mutattak: a legkevésbé kifejeződő gének voltak a legrövidebbek [22]. A metilációnak a transzkripció elongációs szakaszára való hatását gombák és emlősök körében is igazolták [23, 24]. Lörincz és mtsai megállapították, hogy az intragenikus metiláció gátolja a gén, így az int- ronokban elhelyezkedő transzpozonok expresszióját is [24]. Azt feltételezik, hogy a metiláció iniciálja az adott szakasz kondenzálódását, ezáltal csökkenti az RNS-polimeráz II múködésének hatékonyságát [24].

\section{A DNS-metiláció hatása a transzpozonok müködésére}

A DNS-metiláció egyik jelentős funkciója a transzpozonok múködésének, transzkripciójának szabályozása [15]. A beékelődött repetitív elemek a humán genom megközelítóleg 44-45\%-át adják $[25,26]$. Ezeken a szakaszokon belül 5 eltérő típust különböztetünk meg: a LINE (hosszú közbeiktatott szakasz), a SINE (rövid közbeiktatott szakasz), a DNS-transzpozonok, az LTRretrotranszpozonok [26] és az SVA elemek [27]. Emlősökben a transzpozábilis elemek közül a retrotranszpozonok vannak többségben, a DNS-transzpozonok kis részben képviseltetik magukat, illetve mutációk következtében áthelyeződésre képtelenné váltak [26]. Az LTR-retrotranszpozonok is túlnyomórészt inaktívak, csupán az úgynevezett humán endogén retrovírusok (HERV) között van aktív forma [26]. A LINE, SINE, illetve SVA elemek több aktív típussal rendelkező, nem LTR típusú retrotranszpozonok [26]. A fenti mobilis genetikai elemek a genomba való véletlenszerü beékelődésükkel a DNS instabilitását okozhatják [9], illetve különböző gének mutációját idézhetik elő, ami különböző betegségek [27], a haemophilia, a mellrák és az Apertszindróma kialakulásához vezet [28]. A retrotranszpozonok múködésével járó genombeli változások tehát érthetővé teszik a DNS-metiláció azon szerepének fontosságát, miszerint képes a DNS kondenzált állapotát előidézni, így a transzpozábilis elemek átíródását is megakadályozni [24]. Az említett funkció olyannyira jelentős, hogy 1997-ben Yoder és mtsai az 5-metilcitozin elsődleges feladatának a transzpozonokkal szembeni védelmet gondolták [29]. Azok a transzpozonok, amelyek promótere metilált, nem mutatnak aktivitást, illetve az 5-metilcitozin hipermutabilitása által lehetséges citozin-timin csere az érintett promóter szakaszban teljesen múködésképtelenné teheti az adott mobilis genetikai elemet [29]. A DNS-metiláció transzpozábilis elemekkel szembeni szabályozó szerepét nemcsak eukarióták esetén figyelhetjük meg, hanem már a prokariótákban is megjelenik [3]. A Gammaproteobacteria tagjai az IS10 és IS50 bakteriális transzpozonok áthelyeződését két különböző módon szabályozzák a Dam metiláz segítségével $[3,6]$. Az IS10 transzpozáz enzim promóterének metilálása esetén az RNS-polimeráz nem képes kötődni, így a transzkripció gátolttá válik [30]. A másik mechanizmus során mind az IS10, mind az IS50 esetén a transzpozon terminális szakaszainak metilálása megakadályozza a transzpozáz enzim múködését az adott szakaszon [31]. 


\section{A DNS-metiláció szabályozása}

Jelen összefoglaló cikkünkben elsősorban az eukarióta genom regulációjában részt vevő 5-metilcitozin szerepét szeretnénk részletesen bemutatni. A DNS metilációja folyamatosan, dinamikusan változó epigenetikai módosulás, amelyet különböző enzimek tesznek lehetővé [32].

A metilcsoport és a citozin közötti kovalens kötés létrejöttét a (citozin-5)-metiltranszferázok katalizálják [33]. Emlősökben a DNS metiltranszferáz 3A és 3B (DNMT3A, DNMT3B) enzimek de novo aktivitásúak, míg a DNMT1 a metiláció fenntartásáért felelős a DNSreplikáció során $[34,35]$.

A metiláció aktív eltávolítása az úgynevezett TET metilcitozin dioxigenáz (TET) enzimek segítségével történik [36-38]. A TETl enzim az 5-metilcitozin 5-hidroximetilcitozinná (hmC) való alakításáért felelős [36]. Amellett a hmC-t az $5 \mathrm{mC}$ aktív eltávolítás köztitermékének vélik, azt is feltételezik, hogy azon passzív mechanizmus része is, amely során a DNMTl kevésbé ismeri fel a hmC-módosulatokat, így a replikáció közben történő új DNS-szál metilációja nem megfelelő hatásfokkal jön létre [39]. A TET enzimek az 5mC-ből hmC továbboxidálásával képesek 5 -formilcitozint ( $5 \mathrm{fC})$, illetve 5-karboxicitozint $(5 \mathrm{caC})$ is létrehozni [37]. A timin-DNS glikoziláz (TDG) enzim képes az 5caC-t felismerni és eltávolítani a DNS-ból, így a TET és TDG enzimek müködése végső soron a metilált citozin metilálatlan citozinra való cseréjét képes indukálni, a BER (báziskivágásos hibajavítás) típusú DNS-hibajavítási rendszeren keresztül [38].

Jelentős szereppel bírnak még például az AID/ APOBEC enzimek is. Az AID/APOBEC enzimcsalád fehérjéi dezaminázok, amelyek DNS és RNS esetén is képesek a citidint uridinná alakítani, ezáltal mutációt létrehozni [40]. Az APOBECl enzim egy lipidtranszportban részt vevő fehérje mRNS-ét módosítja, míg az APOBEC3 enzimek bizonyos vírusfertőzésekkel szembeni védekezésben, illetve bizonyos retrotranszpozon áthelyeződésének megakadályozásában vesznek részt [41]. Az AID enzimek egyrészt a B-sejtekben az antitestek variábilis régiójának óriási változatosságát létrehozó szomatikus hipermutációban, illetve fertőzés után történő rekombinációban játszanak szerepet [41].

Korábban az 5-metilcitozin dezaminációját alapvetően spontán folyamatnak gondolták $[42,43]$. Mára azonban bebizonyosodott, hogy aktív folyamat is lehet, az AID és APOBECl enzimek 5-metilcitozin dezaminázként is múködnek egyszálú DNS esetén [44, 45]. A dezamináció következtében szintén mutáció jelenhet meg a genom érintett pozíciójában, timin helyezkedik el guanin bázissal szemben, vagy e helytelen bázispárosodás kijavítása esetén a korábban metilált citozin demetilációja történik meg [44]. A dezaminálódás következtében keletkező timint erre specifikus glikoziláz enzimek távolítják el, mint például a már említett TDG enzimek [46]. E két fehérjét kódoló gén együtt fejeződik ki, illetve szintén együtt expresszálódik egyéb pluripotenciát kialakító génekkel a petesejtben, embrionális csírasejtekben és embrionális össejtekben [44]. A fent említett koexpresszióból Morgan és mtsai arra következtetnek, hogy ezek az enzimek fontos szerepet töltenek be az epigenetikai újraprogramozás, a sejtek differenciálódása, illetve akár különböző betegségek, mint például a tumoros megbetegedések kialakulása során is [44]. A DNS-metiláció és -demetiláció folyamatok összefoglalása a 3. ábrán látható $[36,37,38,42,43,47,48]$.

$\mathrm{Az}$ AID enzimek preferenciát mutatnak a A-G-5mCG szekvenciarészletekre [44], míg a DNMT enzimek a CpG-dinukleotidokon kívül nem bírnak pontosabb DNS-specificitással [32]. A fentiek tükrében a módosítandó DNS-szakasz célzásának mechanizmusa nem tisztázott [32]. A DNS-metilációs célpontszakasz meghatározásában tölthet be szerepet például a kettes, illetve hármas Polycomb represszor komplex esetén az EZH2es alegység, amely közvetlen kapcsolatot hoz létre a DNMT1 enzimekkel, így irányítva azokat az EZH2 célgénjeinek promóteréhez, ezáltal szabályozva az érintett gének metilációját [49]. Hasonló szereppel rendelkezhet az E2F6, amely Velasco és mtsai kutatása alapján a DNMT3B enzimeket irányítja bizonyos csíravonal-génekhez [50], illetve a PIWI-asszociált RNS-ek (piRNSek) [51] és a hosszú nem-kódoló RNS-ek (lncRNS-ek) is [32].

A piRNS-ek, amelyek a kis nem-kódoló RNS-ek csoportjába tartoznak [52], képesek az úgynevezett PIWIfehérjékkel komplexet alkotni, ezáltal a piRNS-sel komplementer transzpozonokat hasítani [52].

Fu és mtsai azt feltételezik, hogy a piRNS-ek nemcsak a transzpozábilis elemek csendesítésében vesznek részt, hanem az adott piRNS-nek megfelelő fehérjét kódoló génszakasz metilációját is képesek indukálni [51]. Úgy vélik, hogy fóként azok a piRNS-ek bírnak ilyen szereppel, amelyek kódoló szakasza alacsony kópiaszámban van jelen a DNS-ben [51]. Az érintett génszakasz megtalálásának mechanizmusa a kutatócsoport elgondolása szerint a bázis-komplementaritáson alapszik, miszerint szükséges, hogy az adott piRNS több mint 8 bázisnyi komplementer szakasszal rendelkezzen az adott CpGnukleotidokkal szomszédos DNS- vagy érett mRNS-szakasszal [51].

A piRNS-eken kívül az úgynevezett hosszú nem-kódoló RNS-ek is rendelkeznek DNS-metilációt szabályozó funkcióval [32]. Az ecCEBP lncRNS például a DNMTl enzimhez kötődve specifikusan a CEBPA locus promóterének metilációját szabályozza [53]. További példák közé tartozik a központi idegrendszer Dali nevú lncRNS-e, amely szintén a DNMTl-gyel alkot komplexet [54]. A lncRNS-ek e metilációt irányító funkciója mellett ismert olyan példa is, ami esetén a lncRNS expressziója szabályozott DNS-metiláció által [55]. A fenti jelenség révén a DNS-metiláció aberráns mintázata daganatos elváltozásokhoz vezethet [55]. A lncRNS-ek tehát kapcsolatba hozhatók daganatos 


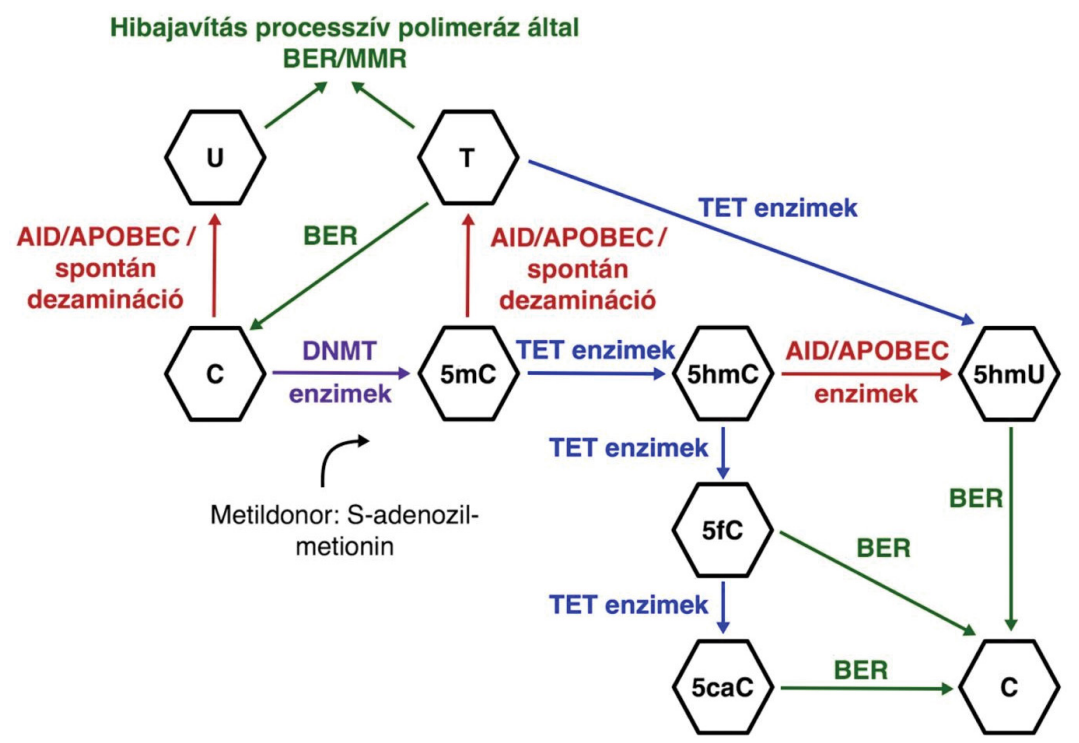

3. ábra

A DNS metiláció-demetiláció folyamata. A metilcsoport kovalens kapcsolása a citozin 5. pozíciójú szenatomjára DNMT enzimek által de novo vagy a replikáció során történik. A metilcsoport közvetlen forrása a metildonor (S-adenozil-metionin) [47]. TET enzimek segítségével a metilcsoport oxidálható 5-hidroximetilcitozinná [36], illetve 5-formil-, majd 5-karboxicitozinná [37]. A TDG enzim képes az 5-karboxicitozin, illetve az 5-formilcitozin kihasítására, mellyel indukálja a BER DNS-hibajavítási mechanizmust, aminek eredményeképpen módosítatlan citozin kerül az apirimidines helyre [38]. Az $5 \mathrm{mC}$ és az 5hmC módosulatok az AID/APOBEC enzimek által dezaminálódhatnak timinné (T), illetve 5-hidroximetiluracillá (5hmU) [48]. Mindkét bázismódosulás BER hibajavítási mechanizmus által, illetve a timin processzív polimeráz általi BER/MMR mechanizmusok által is kijavításra kerülhet [48]. A dezaminálódás spontán folyamat is lehet $[42,43]$

AID/APOBEC = aktivitásindukált dezamináz/apolipoprotein B mRNS-módosító enzim, katalitikus polipeptidszerú; BER = báziskivágásos hibajaví tás; DNMT = DNS-metiltranszferáz; MMR = mismatch repair, DNS-hibajavítási mechanizmus; TET = TET metilcitozin dioxigenáz

Az ábra forrása: Dominguez és mtsai [48] alapján, módosítva
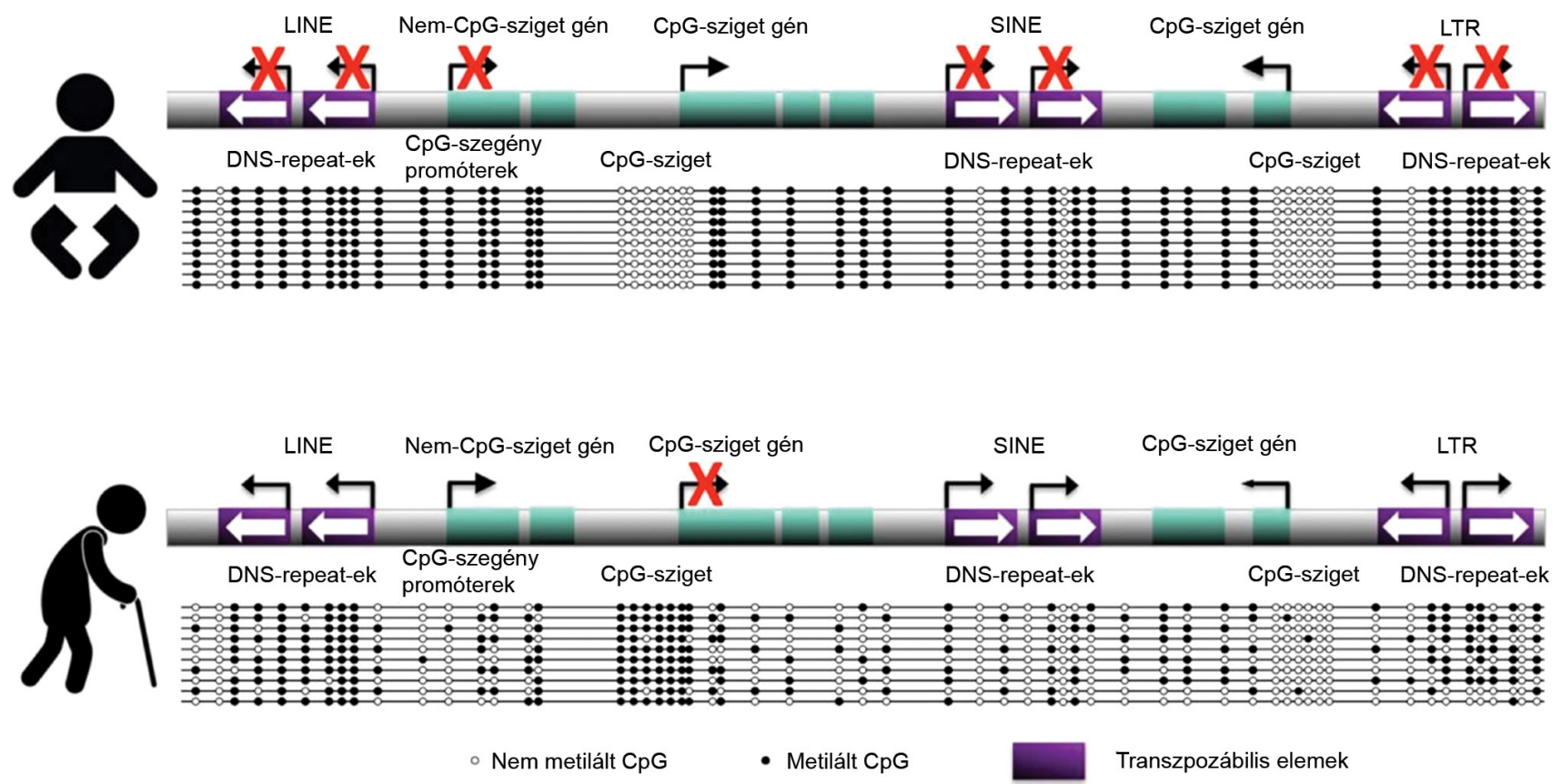

4. ábra

A DNS-metiláció változásai az öregedés során. Fiatal emlósökben globális hipermetiláció mellett a promóterek CpG-szigetei nem metiláltak. A globális hipermetiláció a transzpozábilis elemeket, mint például a LINE és SINE elemeket, illetve az LTR szakaszokat érinti leginkább, amelyek áthelyeződése ezáltal gátolt [9]. A kor előrehaladtával teljes genom szinten a DNS-metiláció mértéke többnyire véletlenszerúen csökken, így az általa csendesített régiók, mint a transzpozonok is aktívvá válhatnak [9]. Ezzel szemben a promóterbeli CpG-szigetek metilálttá válnak, kondenzálódnak, az általuk szabályozott gének kifejeződése megszűnik/csökken

LINE = hosszú közbeiktatott szakasz; LTR = hosszú terminális ismétlődések; SINE = rövid közbeiktatott szakasz

Az ábra forrása: Pal és Tyler [9] alapján 
megbetegedésekkel, illetve számos egyéb humán betegséggel, ami által egyre nagyobb figyelmet kapnak a kutatásban [56].

\section{A DNS-metiláció változása az öregedés során}

Az epigenetikai módosításokra erős hatást gyakorolnak a különböző környezeti tényezők [57]. Ezen különböző környezeti hatások epigenetikai mintázatra gyakorolt hatása az egypetéjű ikrek esetében különösen látványos [57]. Fraga és mtsai kimutatták, hogy mindamellett, hogy az egyedfejlődés kezdeti éveiben az epigenetikai mintázat is teljesen megegyezik, az évek múlásával mind a hisztonfehérjék módosítása, mind a DNS-metiláció eltérővé válik az ikrek között [57]. A fenti folyamatok eredményeképpen válnak az ikrek egy bizonyos mértékig fenotípusosan eltérővé [57]. A környezet hatásán kívül természetesen meghatározóak bizonyos belső faktorok, így például a sejtosztódás során a mintázat esetlegesen nem tökéletes másolása, illetve e hibák későbbi, folyamatos fenntartása („epigenetikai sodródás”) [57].

Az évtizedek múlásával bekövetkező epigenetikai sodródás iránya, eredménye sokszor nem megjósolható, melynek során különböző változások jönnek létre [9]. Ilyen változás az öregedésre jellemző globális hipometiláció, amely többségében a DNS repetitív szakaszait érinti [9]. A DNS-metiláció iniciátora lehet a heterokromatin kialakulásának az érintett szakaszon [24], amelynek megfelelően a CpG-dinukleotidok metiláltságának csökkenő mértéke okozza az alapvetően kondenzált, nem aktív DNS-szakaszok letekeredését [9]. Ha a hipometiláció az előbb említett ismétlődő szakaszokat, így az azokon belül az igen nagy számban jelen lévő retrotranszpozonokat érinti, azok aktiválódhatnak [9]. Az aktív retrotranszpozonok véletlenszerü beékelődésükkel növelik a DNS instabilitását, illetve mutációkat is okozhatnak $[9,25]$.

A globális hipometiláció mellett megfigyelhető a CpGszigetek metilációja is az öregedés során [9]. A fenti folyamat következtében azoknak a géneknek a kifejeződése megszünik/csökken, amelyek promótere és/vagy regulációs régiói metilált $\mathrm{CpG}$-szigetekben gazdagok [9].

Az öregedés és a tumoros megbetegedések kialakulása folyamán is hasonló metilációs változásokat figyeltek meg [58]. Ahogy az egészséges öregedés során, úgy a rákos megbetegedések esetén is globális hipometiláció jellemző, míg bizonyos gének (elsősorban tumorszuppresszor gének) promóterbeli CpG-szigeteinek hipermetilációja történik [58]. Ez azt is maga után vonja, hogy az életkor előrehaladtával növekszik a tumorok létrejöttének valószínúsége [58]. A 4. ábra összefoglalja a DNSmetilációs mintázat öregedés során végbemenő változásait [9].

Bizonyos gének korfüggő DNS-metilációs változása alapján megbecsülhető az adott személyek biológiai kora. Weidner és mtsai három olyan gént (ITGA2B,
ASPA, PDE4C) azonosítottak, amelyeknek korfüggő metilációs szintje alapján vérmintából meghatározható az ún. biológiai kor, kevesebb mint 5 év eltéréssel az adott személy kronológiai életkorától [59]. Steve Horvath szöveti mintákból 353 olyan CpG-dinukleotidot karakterizált, amelyek metilációs szintje alapján megbecsülhető az adott személy úgynevezett DNS-metilációs kora $[60,61]$. Ez egy olyan epigenetikai óra $[60,61]$, ami segítséget nyújthat bizonyos fejlődésbiológiai, öregedésbeli és rákos megbetegedésekkel kapcsolatos kérdések megválaszolásában $[60,61]$.

\section{A DNS-metiláció megváltozása daganatokban}

Gautrey és mtsai bizonyos gének esetén nemcsak korcsoportok szerint különböző, hanem azonos korosztályon belül is eltérő DNS-metilációs mintázatot írtak le, amiből arra következtettek, hogy a DNS-metilációs mintázat az adott személy különböző, öregedéshez kapcsolható betegségekre, köztük a daganatos megbetegedésekre való hajlamát is meghatározhatja [58]. Kortól függetlenül is elmondható, hogy az epigenetikai módosítások, így a DNS-metiláció is fontos szereppel bír számos betegség patomechanizmusában [62]. Az epigenetikai mintázat utódsejtekre való öröklődése során adódó problémák a magzati fejlődés alatt gyermekkori rákos megbetegedésekhez, illetve a DNS-metilációs mintázat öregedés során bekövetkező megváltozása szintén tumorok képződéséhez vezethet [62].

\section{Globális hipometiláció}

A DNS-metiláció teljes genom szinten való csökkenése, az ún. globális hipometiláció volt az egyik elsőként megfigyelt változás rákos sejtekben [62], amelyet a vastagbél jóindulatú és rosszindulatú daganatos eltéréseiben egyaránt kimutattak [63]. Mellrák esetén a rosszindulatú elváltozásokban kisebb mértékű globális hipometilációt találtak, mint a jóindulatú emlődaganatokban, de egy másik tanulmányban ennek fordítottját tapasztalták [64].

A hipometiláció leggyakrabban a már említett ismétlődő DNS-szakaszok esetén figyelhető meg [64]. Több kutatás során észlelték a LINE-1 retrotranszpozonok metiláltságának csökkenését különféle rákos megbetegedésekben [65]. Phokaew és mtsai ép orális epithelium és pikkelysejtes carcinoma minták 17 locusának vizsgálata során [65] kimutatták, hogy a különböző locusok LINE-1-metiláltsága eltérő mértéket mutat egy kromoszómán belül, illetve szövetek között is. Az 5-metilcitozin szintjének globális csökkenése jellemző a rákos sejtekben, viszont az egyes 5-metilcitozinok különböző mértékben érintettek, attól függően, hogy hol helyezkednek el a genomban [65]. A fentiekból adódóan a különböző LINE-1 locusokat vizsgálva, esetleg található olyan, amely specifikus információkat nyújt a tumor fej- 
lődéséről, így a diagnosztika területén is jól használható markerré válhat [65].

A kimondottan nagy kópiaszámmal előforduló retrotranszpozonok, így például a LINE-1 mellett, bizonyos ráktípusokban megfigyelték a mérsékelt mennyiségben ismétlődő szakaszok, a szatellitarégiók, illetve egyes gének hipometilációjának megjelenését is [64]. Ilyen kevesebb kópiával rendelkező retrotranszpozon-osztály például a HERV-K retrotranszpozon-osztály [64]. Nem

1. táblázat $\mid$ Fontos tumorszuppresszor markerek vastagbéldaganatokban (Az alább szereplő markerek hipermetilációt mutatnak rákos megbetegedés esetén)

\begin{tabular}{|c|c|c|c|}
\hline Minta típusa & $\begin{array}{l}\text { Gén } \\
\text { szimbóluma }\end{array}$ & Gén neve & Referencia \\
\hline \multirow[t]{8}{*}{ Szövet } & IRF8 & Interferon regulációs faktor 8 & {$[71]$} \\
\hline & TIMP3 & $\begin{array}{l}\text { Metalloproteináz } 3 \text { szöveti } \\
\text { inhibitora }\end{array}$ & {$[71]$} \\
\hline & CXCL2 & $\begin{array}{l}\text { Kemokin (C-X-C motívum) } \\
\text { ligandum } 2\end{array}$ & [71] \\
\hline & $\begin{array}{l}\text { CDKN2A/ } \\
\text { P16 }\end{array}$ & $\begin{array}{l}\text { ciklin-függő kináz inhibitor } \\
2 \mathrm{~A}\end{array}$ & {$[72]$} \\
\hline & GSTPl & glutation-S-transzferáz Pl & {$[72]$} \\
\hline & SFRPl & $\begin{array}{l}\text { Szekretált frizzled-rokon } \\
\text { fehérje } 1\end{array}$ & {$[73-76]$} \\
\hline & SFRP2 & $\begin{array}{l}\text { Szekretált frizzled-rokon } \\
\text { fehérje } 2\end{array}$ & {$[73-76]$} \\
\hline & $\mathrm{APC}$ & Adenomatosus polyposis coli & {$[73]$} \\
\hline \multirow[t]{5}{*}{ Széklet } & ITGA4 & Integrin alfa 4 & {$[77]$} \\
\hline & MGMT & $\begin{array}{l}\text { O-6-metilguanin-DNS } \\
\text { metiltranszferáz }\end{array}$ & {$[78]$} \\
\hline & PGR & Progeszteronreceptor & {$[79]$} \\
\hline & SFRP2 & $\begin{array}{l}\text { Szekretált frizzled-rokon } \\
\text { fehérje } 2\end{array}$ & [79] \\
\hline & SFRP5 & $\begin{array}{l}\text { Szekretált frizzled-rokon } \\
\text { fehérje } 5\end{array}$ & [79] \\
\hline \multirow{9}{*}{$\begin{array}{l}\text { Vérszé- } \\
\text { rum/ } \\
\text { plazma }\end{array}$} & $\begin{array}{l}\text { CDKN2A/ } \\
\text { P16 }\end{array}$ & $\begin{array}{l}\text { Ciklin-függő kináz inhibitor } \\
\text { 2A }\end{array}$ & {$[80]$} \\
\hline & NGFR & $\begin{array}{l}\text { Idegi növekedési faktor } \\
\text { receptor }\end{array}$ & {$[81]$} \\
\hline & RUNX3 & $\begin{array}{l}\text { Runt-rokon transzkripciós } \\
\text { faktor } 3\end{array}$ & {$[80]$} \\
\hline & SEPT9 & Septin 9 & {$[81-83]$} \\
\hline & TMEFF2 & $\begin{array}{l}\text { Transzmembrán protein } \\
\text { EGF-szerű és két follisztatin- } \\
\text { szerű doménnel } 2\end{array}$ & {$[81]$} \\
\hline & SFRPl & $\begin{array}{l}\text { Szekretált frizzled-rokon } \\
\text { fehérje } 1\end{array}$ & [84] \\
\hline & SFRP2 & $\begin{array}{l}\text { Szekretált frizzled-rokon } \\
\text { fehérje } 2\end{array}$ & {$[84]$} \\
\hline & SDC2 & Szindekán-2 & {$[84]$} \\
\hline & PRIMAl & $\begin{array}{l}\text { Prolin-gazdag membrán } \\
\text { horgony } 1\end{array}$ & {$[84]$} \\
\hline
\end{tabular}

A táblázat forrása: Kalmár [70] alapján, módosítva. retrovirális eredetű, kisebb mértékben ismétlődő DNSszakaszok hipometilációját szintén kimutatták neuroblastoma esetén [64]. Gama-Sosa és mtsai jóindulatú és malignus elváltozások fragmentált DNS-e 5-metilcitozin-tartalmának elemzése során azt tapasztalták, hogy a nagy, illetve kisebb kópiaszámmal rendelkező ismétlődő DNS-szakaszok mellett bizonyos gének (például Martin és mtsai szerint a pS2 fehérjét kódoló szakasz promóter régiója mellrák esetén [66]) hipometilációja is megfigyelhető [67].

Korábban úgy gondolták, hogy a nagymértékű demetiláció spontán dezamináció révén jön létre, viszont mára tisztázottá vált, hogy e folyamat TET, illetve bizonyos AID/APOBEC enzimek közremúködésével megy végbe [45].

\section{Lokális hipermetiláció}

A hipermetiláció - a hipometilációval ellentétben - nem globálisan jelenik meg a genomban, hanem elsősorban bizonyos gének (a daganatos megbetegedésekben általában a tumorszuppresszor gének) promóteréhez tartozó CpG-szigeteket érinti [58]. A CpG-szigetek alapvetően védettek a metilációval szemben [68]. A promóter hipermetilációja az adott DNS-szakasz kompaktabbá válását, így átíródásának csökkenését/megszűnését okozza [58]. Régóta ismert, hogy bizonyos, vastagbéldaganatokban azonosított hipermetilált gének, például egyes tumorszuppresszor gének inaktivációja fokozza a sejtproliferációt, így szelektív előnyt jelenthet a tumorsejtek számára $[69,70]$. Az 1. táblázat a vastagbéldaganatokban legfontosabb hipermetilált tumorszuppresszor markereket foglalja össze [71-84].

A promóter szakaszok hipermetilációjával szemben a géntest metilációja DNMT3B enzim jelenlététől függően az expresszió fokozódásával jár [85]. Ennek mechanizmusa, illetve rákos megbetegedésekben betöltött szerepe sok kutatás célpontja [85-88]. Például Irizarry és mtsai humán vastagbélrák esetén mutatták ki [88], hogy a DNS-metilációs mintázat változása a géntesteket is érinti $[73,88]$. Azáltal, hogy a rákos megbetegedésekben fontos szerepet tölt be az intragenikus DNS-metiláció, fontos terápiás célpont lehet e betegségek kezelése során [85].

\section{A DNS-metiláció változásainak lehetséges hatásai a genetikai instabilitásra és a mutációk kialakulására}

A genetikai és epigenetikai szabályozó folyamatok egymás mellett múködő, egymással is kölcsönhatásban lévő jelenségek, amelyek együttesen befolyásolják a gének múködését, azaz a mutációs eltérések aberráns metilációs változásokat okozhatnak, illetve a DNS-metilációs eltérések mutációk kialakulásához vezethetnek [89]. Ismert, hogy a metilált CpG-dinukleotidok esetén nagyobb a 
mutációs ráta (C-T mutáció), annak a mechanizmusáról azonban keveset tudunk, hogy a metilációs szint megváltozása hogyan, milyen mechanizmussal okozza a mutációs ráta megváltozását. A közelmúltban [90] végzett egyedi nukleotid felbontású, teljes genomszintű DNSmetilációs vizsgálatok eredményei alapján lehetőség nyílt a DNS-metiláció mutációs gyakoriságra tett hatásának pontosabb tanulmányozására. A metilált CpG-helyeken (CpG site) nagyobb mutációs arány jellemző, mint a nem metilált CpG-helyeken $[42,90]$. A metilált CpG helyeken belül azonban az alacsony-közepes (20-40\%os) és a közepes (40-60\%-os) metilációs szintet mutatóak bizonyultak mutációs gyakoriság szempontjából kiemelkedőnek. Ez a jelenség bizonyos „génszegény” kromoszómákon (4., 13., 18. és 21.) még inkább megfigyelhető, ami arra utal, hogy a magas, nem-random mutációs (SNP) mintázat az intergénikus és intronikus régiókra fokozottan jellemző a promóter és CpG-sziget régiókban tapasztalthoz képest [90]. A DNS-metiláció eukariótákban betöltött szerepét tárgyaló fejezetben is utaltunk már arra, hogy a DNS-metiláció megváltoztathatja az adott DNS mutációs rátáját [16]. A fenti jelenség az 5-metilcitozin hipermutabilitásából fakadhat, ugyanis ez a metilált bázismódosulás sokkal könnyebben dezaminálódik (például az AID/APOBEC enzimcsalád segítségével vagy spontán módon), mint a citozin, így legtöbbször timinné, mint inkább uracillá alakul [16, 91]. A globális DNS-metiláció változása által érintett, aktív mobilis genetikai elemek a genomba való véletlenszerű inszertálódásukkal szintén a DNS instabilitását okozhatják, illetve mutációkhoz is vezethetnek [9, 27].

\section{Következtetés és kitekintés}

A DNS szekvenciabeli megváltozása (mutációk) [92, 93] mellett az epigenetikai mintázat, és azon keresztül a genom transzkripciós aktivitásának módosulása is hozzájárul a különböző örökölhető fenotípusok kialakulásához az evolúció során [94]. Skinner általánosan nem elfogadott újszerű elmélete szerint az epigenetikai mintázat környezet által indukált módosulása, így a DNS-metilációs mintázatban bekövetkező változások generációk közti öröklődése nagy jelentőséggel bír nemcsak az evolúcióbiológia és a fenotípusos változatosság bővülése, hanem a különböző betegségek - köztük a daganatos megbetegedések - etiológiája szempontjából is [94].

Mivel a DNS-metilációs eltérések a genetikai eltérésekkel összemérhető gyakorisággal fordulnak elő daganatos megbetegedésekben $[95,96]$, és - a mutációkhoz hasonlóan - a szöveti DNS-en kívül a véráramban keringő DNS-ben is megjelennek [97, 98], a megbetegedésre specifikus DNS-metilációs markerek azonosításával és kimutatásával lehetőség nyílik a daganatos betegségek minimál invazív epigenetikai diagnosztikájára is $[97$, 98]. A különböző epigenetikai jelenségek a diagnosztikai potenciáljuk mellett fontos szerepet játszhatnak rákos megbetegedésekre irányuló terápiák esetén is. Kiemelke- dő jelentőségúek a hisztonfehérjék módosításait befolyásoló terápiás szerek, mint például a hiszton-deacetilázinhibitor romidepsin, belinostat, panobinostat [99], vorinostat [100], illetve számos hasonló HDAC gátlószer, amelyek még klinikai vizsgálatok alatt állnak [99]. Mindemellett a DNS-metiláció mesterséges szabályozására is találunk már forgalomban lévő ágenseket, mint a DNMT-inhibitor 5-azacitidin, vagy az 5-aza-2'-deoxicitidin, illetve még vizsgálat alatt álló terápiás megoldásokat, mint például az MG98 antiszensz RNS, amely a DNMTl enzim mRNS-éhez kötődve annak transzlálódását képes gátolni [101]. A különböző epigenetikai jelenségek mesterséges befolyásolása tehát - indukálható és reverzibilis mivoltuk miatt - funkcionális epigenetikai terápia alapjául szolgálhat a jövőben $[1,102]$.

Anyagi támogatás: A közlemény a Nemzeti Kutatási, Fejlesztési és Innovációs Hivatal (NVKP_16-1-20160004) és az Országos Tudományos Kutatási Alapprogramok (OTKA-K111743) támogatásával készült.

Szerzői munkamegosztás: Sz. K. A., G. O.: A szakirodalom kutatása, válogatása, feldolgozása, a kézirat megírása. K. A., B. B. K., N. Zs. B., M. E.: A szakirodalom kutatása, feldolgozása. I. P., T. Zs.: A kézirat kritikus átolvasása. M. B.: Szakmai iránymutatás, a kézirat kritikus átolvasása. A cikk végleges változatát valamennyi szerző elolvasta és jóváhagyta.

Érdekeltségek: A szerzőknek nincsenek érdekeltségeik.

\section{Irodalom}

[1] Urbán SV, Benevolenskaya E, Kiss J, et al. Beyond genetics - The emerging role of epigenetics and its clinical aspects. [A genetikán is túl - Az epigenetika elóretörése és orvosi vonatkozásai.] Orv Hetil. 2012; 153: 214-221. [Hungarian]

[2] Rana AK, Ankri S. Reviving the RNA world: An insight into the appearance of RNA methyltransferases. Front Genet. 2016; 7: 99.

[3] Marinus MG, Casadesus J. Roles of DNA adenine methylation in host-pathogen interactions: mismatch repair, transcriptional regulation, and more. FEMS Microbiol Rev. 2009; 33: 488-503.

[4] Blow MJ, Clark TA, Daum CG, et al. The epigenomic landscape of prokaryotes. PLoS Genet. 2016; 12: e1005854.

[5] Seshasayee AS, Singh P, Krishna S. Context-dependent conservation of DNA methyltransferases in bacteria. Nucleic Acids Res. 2012; 40: 7066-7073

[6] Wion D, Casadesús J. N6-methyl-adenine: an epigenetic signal for DNA-protein interactions. Nat Rev Microbiol. 2006; 4: 183-192.

[7] Sternberg N, Coulby J. Cleavage of the bacteriophage Pl packaging site (pac) is regulated by adenine methylation. Proc Natl Acad Sci USA 1990; 87: 8070-8074.

[8] Wilson AS, Power BE, Molloy PL. DNA hypomethylation and human diseases. Biochim Biophys Acta 2007; 1775: 138-162.

[9] Pal S, Tyler JK. Epigenetics and aging. Sci Adv. 2016; 2: el600584.

[10] Clouaire T, Stancheva I. Methyl-CpG binding proteins: specialized transcriptional repressors or structural components of chromatin? Cell Mol Life Sci. 2008; 65: 1509-1522. 
[11] Ling C, Groop L. Epigenetics: a molecular link between environmental factors and type 2 diabetes. Diabetes 2009; 58: 27182725.

[12] Riggs AD, Pfeifer GP. X-chromosome inactivation and cell memory. Trends Genet. 1992; 8: 169-174.

[13] Li E, Beard C, Jaenisch R. Role for DNA methylation in genomic imprinting. Nature 1993; 366: 362-365.

[14] Yamagata Y, Szabó P, Szüts D, et al. Rapid turnover of DNA methylation in human cells. Epigenetics 2012; 7: 141-145.

[15] Feng S, Cokus SJ, Zhang X, et al. Conservation and divergence of methylation patterning in plants and animals. Proc Natl Acad Sci USA 2010; 107: 8689-8694.

[16] Dixon GB, Bay LK, Matz MV. Evolutionary consequences of DNA methylation in a basal metazoan. Mol Biol Evol. 2016; 33: 2285-2293.

[17] Suzuki MM, Kerr AR, De Sousa D, et al. CpG methylation is targeted to transcription units in an invertebrate genome. Genome Res. 2007; 17: 625-631.

[18] Capuano F, Mülleder M, Kok R, et al. Cytosine DNA methylation is found in Drosophila melanogaster but absent in Saccharomyces cerevisiae, Schizosaccharomyces pombe, and other yeast species. Anal Chem. 2014; 86: 3697-3702.

[19] Simpson VJ, Johnson TE, Hammen RF. Caenorbabditis elegans DNA does not contain 5-methylcytosine at any time during development or aging. Nucleic Acids Res. 1986; 14: 6711-6719.

[20] Suzuki MM, Bird A. DNA methylation landscapes: provocative insights from epigenomics. Nat Rev Genet. 2008; 9: 465-476.

[21] SanMiguel P, Tikhonov A, Jin YK, et al. Nested retrotransposons in the intergenic regions of the maize genome. Science 1996; 274: 765-768.

[22] Zilberman D, Gehring M, Tran RK, et al. Genome-wide analysis of Arabidopsis thaliana DNA methylation uncovers an interdependence between methylation and transcription. Nat Genet. 2007; 39: 61-69.

[23] Rountree MR, Selker EU. DNA methylation inhibits elongation but not initiation of transcription in Neurospora crassa. Genes Dev. 1997; 11: 2383-2395.

[24] Lorincz MC, Dickerson DR, Schmitt M, et al. Intragenic DNA methylation alters chromatin structure and elongation efficiency in mammalian cells. Nat Struct Mol Biol. 2004; 11: 1068-1075.

[25] Mills RE, Bennett EA, Iskow RC, et al. Which transposable elements are active in the human genome? Trends Genet. 2007; 23 : 183-191.

[26] Deininger PL, Moran JV, Batzer MA, et al. Mobile elements and mammalian genome evolution. Curr Opin Genet Dev. 2003; 13 : 651-658.

[27] Ostertag EM, Goodier JL, Zhang Y, et al. SVA elements are nonautonomous retrotransposons that cause disease in humans. Am J Hum Genet. 2003; 73: 1444-1451.

[28] Batzer MA, Deininger PL. Alu repeats and human genomic diversity. Nat Rev Genet. 2002; 3: 370-379.

[29] Yoder JA, Walsh CP, Bestor TH. Cytosine methylation and the ecology of intragenomic parasites. Trends Genet. 1997; 13: 335-340.

[30] Roberts D, Hoopes BC, McClure WR, et al. IS10 transposition is regulated by DNA adenine methylation. Cell 1985; 43: 117130 .

[31] Dodson KW, Berg DE. Factors affecting transposition activity of IS 50 and Tn 5 ends. Gene 1989; 76: 207-213.

[32] Zhao Y, Sun H, Wang H. Long noncoding RNAs in DNA methylation: new players stepping into the old game. Cell Biosci. 2016; 6: 45 .

[33] Bester TH. Cloning of a mammalian DNA methyltransferase. Gene 1988; 74: 9-12.

[34] Lei H, Oh SP, Okano M, et al. De novo DNA cytosine methyltransferase activities in mouse embryonic stem cells. Development 1996; 122: 3195-3205.
[35] Okano M, Xie S, Li E. Cloning and characterization of a family of novel mammalian DNA (cytosine-5) methyltransferases. Nat Genet. 1998; 19: 219-220.

[36] Tahiliani M, Koh KP, Shen Y, et al. Conversion of 5-methylcytosine to 5 -hydroxymethylcytosine in mammalian DNA by MLL partner TETl. Science 2009; 324: 930-935.

[37] Ito S, Shen L, Dai Q, et al. Tet proteins can convert 5-methylcytosine to 5-formylcytosine and 5-carboxylcytosine. Science 2011; 333: 1300-1303.

[38] He YF, Li BZ, Li Z, et al. Tet-mediated formation of 5-carboxylcytosine and its excision by TDG in mammalian DNA. Science 2011; 333: 1303-1307.

[39] Valinluck V, Sowers LC. Endogenous cytosine damage products alter the site selectivity of human DNA maintenance methyltransferase DNMTl. Cancer Res. 2007; 67: 946-950.

[40] Conticello SG. The AID/APOBEC family of nucleic acid mutators. Genome Biol. 2008; 9: 229.

[41] Siriwardena SU, Chen K, Bhagwat AS. Functions and malfunctions of mammalian DNA-cytosine deaminases. Chem Rev. 2016; 116: 12688-12710.

[42] Mugal CF, Ellegren H. Substitution rate variation at human $\mathrm{CpG}$ sites correlates with non- $\mathrm{CpG}$ divergence, methylation level and GC content. Genome Biol. 2011; 12: R58.

[43] Holliday R, Grigg GW. DNA methylation and mutation. Mutat Res. 1993; 285: 61-67.

[44] Morgan HD, Dean W, Coker HA, et al. Activation-induced cytidine deaminase deaminates 5-methylcytosine in DNA and is expressed in pluripotent tissues: implications for epigenetic reprogramming. J Biol Chem. 2004; 279: 52353-52360.

[45] Bochtler M, Kolano A, Xu GL. DNA demethylation pathways: Additional players and regulators. Bioessays 2017; 39: 1-13.

[46] Hardeland U, Bentele M, Jiricny J, et al. The versatile thymine DNA-glycosylase: a comparative characterization of the human, Drosophila and fission yeast orthologs. Nucleic Acids Res. 2003; 31: 2261-2271.

[47] Niculescu MD, Zeisel SH. Diet, methyl donors and DNA methylation: interactions between dietary folate, methionine and choline. J Nutr. 2002; 132: 2333S-2335S.

[48] Dominguez PM, Shaknovich R. Epigenetic function of activation-induced cytidine deaminase and its link to lymphomagenesis. Front Immunol. 2014; 5: 642.

[49] Viré E, Brenner C, Deplus R, et al. The Polycomb group protein EZH2 directly controls DNA methylation. Nature 2006; 439: 871-874.

[50] Velasco G, Hubé F, Rollin J, et al. Dnmt3b recruitment through E2F6 transcriptional repressor mediates germ-line gene silencing in murine somatic tissues. Proc Natl Acad Sci USA 2010; 107: 9281-9286.

[51] Fu A, Jacobs DI, Zhu Y. Epigenome-wide analysis of piRNAs in gene-specific DNA methylation. RNA Biol. 2014; 11: 13011312.

[52] Siomi MC, Sato K, Pezic D, et al. PIWI-interacting small RNAs: the vanguard of genome defence. Nat Rev Mol Cell Biol. 2011; 12: $246-258$.

[53] Di Ruscio A, Ebralidze AK, Benoukraf T, et al. DNMTl-interacting RNAs block gene-specific DNA methylation. Nature 2013; 503: 371-376.

[54] Chalei V, Sansom SN, Kong L, et al. The long non-coding RNA Dali is an epigenetic regulator of neural differentiation. Elife 2014; 3: e04530.

[55] Zhang X, Zhou Y, Mehta KR, et al. A pituitary-derived MEG3 isoform functions as a growth suppressor in tumor cells. J Clin Endocrinol Metab. 2003; 88: 5119-5126.

[56] Nagy Z, Szabó DR, Zsippai A, et al. Relevance of long non-coding RNAs in tumour biology. [A hosszú, nem kódoló RNS-ek jelentősége a daganatbiológiában.] Orv Hetil. 2012; 153: 1494-1501. [Hungarian] 
[57] Fraga MF, Ballestar E, Paz MF, et al. Epigenetic differences arise during the lifetime of monozygotic twins. Proc Natl Acad Sci USA 2005; 102: 10604-10609.

[58] Gautrey HE, van Otterdijk SD, Cordell HJ, et al. DNA methylation abnormalities at gene promoters are extensive and variable in the elderly and phenocopy cancer cells. FASEB J. 2014; 28 : 3261-3272.

[59] Weidner CI, Lin Q, Koch CM, et al. Aging of blood can be tracked by DNA methylation changes at just three CpG sites. Genome Biol. 2014; 15: R24.

[60] Horvath S. DNA methylation age of human tissues and cell types. Genome Biol. 2013; 14: R115.

[61] Horvath S. Erratum to: DNA methylation age of human tissues and cell types. Genome Biol. 2015; 16: 96.

[62] Feinberg AP, Tycko B. The history of cancer epigenetics. Nat Rev Cancer 2004; 4: 143-153.

[63] Goelz SF, Vogelstein B, Hamilton SR, et al. Hypomethylation of DNA from benign and malignant human colon neoplasms. Science 1985 ; 228 : 187-190.

[64] Ehrlich M. DNA methylation in cancer: too much, but also too little. Oncogene 2002; 21: 5400-5413.

[65] Phokaew C, Kowudtitham S, Subbalekha K, et al. LINE-1 methylation patterns of different loci in normal and cancerous cells. Nucleic Acids Res. 2008; 36: 5704-5712.

[66] Martin V, Ribieras S, Song-Wang XG, et al. Involvement of DNA methylation in the control of the expression of an estrogen-induced breast-cancer-associated protein (pS2) in human breast cancers. J Cell Biochem. 1997; 65: 95-106.

[67] Gama-Sosa MA, Slagel VA, Trewyn RW, et al. The 5-methylcytosine content of DNA from human tumors. Nucleic Acids Res. 1983; 11: 6883-6894.

[68] Long HK, King HW, Patient RK, et al. Protection of CpG islands from DNA methylation is DNA-encoded and evolutionarily conserved. Nucleic Acids Res. 2016; 44: 6693-6706.

[69] Kane MF, Loda M, Gaida GM, et al. Methylation of the hMLHI promoter correlates with lack of expression of hMLHl in sporadic colon tumors and mismatch repair-defective human tumor cell lines. Cancer Res. 1997; 57: 808-811.

[70] Kalmár A. Analysis of genes with altered expression along colorectal tumor formation and their regulatory processes. $\mathrm{PhD}$ thesis. Semmelweis University, Clinical Medicine Doctoral School, Budapest, 2015. [A vastagbéldaganatok kialakulása során megváltozó expressziójú gének és szabályozó folyamataik vizsgálata. Doktori értekezés. Semmelweis Egyetem, Klinikai Orvostudományi Doktori Iskola, Budapest, 2015.] [Hungarian]

[71] Kim YH, Petko Z, Dzieciatkowski S, et al. CpG island methylation of genes accumulates during the adenoma progression step of the multistep pathogenesis of colorectal cancer. Genes Chromosomes Cancer 2006; 45: 781-789.

[72] Lee S, Hwang KS, Lee HJ, et al. Aberrant CpG island hypermethylation of multiple genes in colorectal neoplasia. Lab Invest. 2004; 84: 884-893.

[73] Galamb O, Kalmár A, Péterfia B, et al. Aberrant DNA methylation of WNT pathway genes in the development and progression of CIMP-negative colorectal cancer. Epigenetics 2016; 11: 588602.

[74] Kalmár A, Péterfia B, Hollósi P, et al. DNA hypermethylation and decreased mRNA expression of MAL, PRIMA1, PTGDR and SFRPI in colorectal adenoma and cancer. BMC Cancer $2015 ; 15: 736$

[75] Patai ÁV, Valcz G, Hollósi P, et al. Comprehensive DNA methylation analysis reveals a common ten-gene methylation signature in colorectal adenomas and carcinomas. PLoS One 2015; 10: e0133836.

[76] Silva AL, Dawson SN, Arends MJ, et al. Boosting Wnt activity during colorectal cancer progression through selective hypermethylation of Wnt signaling antagonists. BMC Cancer 2014; 14: 891 .
[77] Ausch C, Kim YH, Tsuchiya KD, et al. Comparative analysis of PCR-based biomarker assay methods for colorectal polyp detection from fecal DNA. Clin Chem. 2009; 55: 1559-1563.

[78] Petko Z, Ghiassi M, Shuber A, et al. Aberrantly methylated CDKN2A, MGMT, and MLHI in colon polyps and in fecal DNA from patients with colorectal polyps. Clin Cancer Res. 2005; 11: 1203-1209.

[79] Müller HM, Oberwalder M, Fiegl H, et al. Methylation changes in faecal DNA: a marker for colorectal cancer screening? Lancet 2004; 363: 1283-1285.

[80] Tan SH, Ida H, Lau QC, et al. Detection of promoter hypermethylation in serum samples of cancer patients by methylationspecific polymerase chain reaction for tumour suppressor genes including RUNX3. Oncol Rep. 2007; 18: 1225-1230.

[81] Lofton-Day C, Model F, Devos T, et al. DNA methylation biomarkers for blood-based colorectal cancer screening. Clin Chem. 2008; 54: 414-423.

[82] Tóth K, Sipos F, Kalmár A, et al. Detection of methylated SEPT9 in plasma is a reliable screening method for both left- and rightsided colon cancers. PLoS One 2012; 7: e46000.

[83] Tóth K, Galamb O, Spisák S, et al. Free circulating DNA based colorectal cancer screening from peripheral blood: the possibility of the methylated septin 9 gene marker. [Szabad DNS-alapú vastagbéldaganat-szúrés perifériás vérből: a metilált szeptin-9 génmarker lehetőségei.] Orv Hetil. 2009; 150: 969-977. [Hungarian]

[84] Barták BK, Kalmár A, Péterfia B, et al. Colorectal adenoma and cancer detection based on altered methylation pattern of SFRPI, SFRP2, SDC2, and PRIMA1 in plasma samples. Epigenetics 2017 Jul 28: 1-13. doi: 10.1080/15592294.2017.1356957. [Epub ahead of print]

[85] Yang X, Han H, De Carvalho DD, et al. Gene body methylation can alter gene expression and is a therapeutic target in cancer. Cancer Cell 2014; 26: 577-590.

[86] Varley KE, Gertz J, Bowling KM, et al. Dynamic DNA methylation across diverse human cell lines and tissues. Genome Res. 2013; 23: 555-567.

[87] Maunakea AK, Nagarajan RP, Bilenky M, et al. Conserved role of intragenic DNA methylation in regulating alternative promoters. Nature 2010; 466: 253-257.

[88] Irizarry RA, Ladd-Acosta C, Wen B, et al. The human colon cancer methylome shows similar hypo- and hypermethylation at conserved tissue-specific CpG island shores. Nat Genet. 2009; 41: 178-186.

[89] Issa JP. The cancer epigenome: Is epigenetic deregulation the chicken or the egg? American Association for Cancer Research Annual Meeting 2015, Philadelphia.

[90] Xia J, Han L, Zhao Z. Investigating the relationship of DNA methylation with mutation rate and allele frequency in the human genome. BMC Genomics 2012; 13: S7.

[91] Shen JC, Rideout WM 3rd, Jones PA. The rate of hydrolytic deamination of 5-methylcytosine in double-stranded DNA. Nucleic Acids Res. 1994; 22: 972-976.

[92] Laland K, Uller T, Feldman M, et al. Does evolutionary theory need a rethink? Nature 2014; 514: 161-164.

[93] Skinner MK. Environmental epigenetics and a unified theory of the molecular aspects of evolution: a neo-Lamarckian concept that facilitates neo-Darwinian evolution. Genome Biol Evol. 2015; 7: 1296-1302.

[94] Skinner MK. Environmental epigenetic transgenerational inheritance and somatic epigenetic mitotic stability. Epigenetics 2011; 6: 838-842.

[95] Esteller M, Herman JG. Cancer as an epigenetic disease: DNA methylation and chromatin alterations in human tumours. J Pathol. 2001; 196: 1-7.

[96] Ushijima T, Asada K. Aberrant DNA methylation in contrast with mutations. Cancer Sci. 2010; 101: 300-305. 
[97] Galanopoulos M, Tsoukalas N, Papanikolaou IS, et al. Abnormal DNA methylation as a cell-free circulating DNA biomarker for colorectal cancer detection: A review of literature. World J Gastrointest Oncol. 2017; 9: 142-152.

[98] Warton K, Samimi G. Methylation of cell-free circulating DNA in the diagnosis of cancer. Front Mol Biosci. 2015; 2: 13.

[99] Eckschlager T, Plch J, Stiborova M, et al. Histone deacetylase inhibitors as anticancer drugs. Int J Mol Sci. 2017; 18: 1414.

[100] Falkenberg KJ, Johnstone RW. Histone deacetylases and their inhibitors in cancer, neurological diseases and immune disorders. Nat Rev Drug Discov. 2014; 13: 673-691.

[101] Yang X, Lay F, Han H, et al. Targeting DNA methylation for epigenetic therapy. Trends Pharmacol Sci. 2010; 31: 536546.
[102] Spisák S, Kalmár A, Galamb O, et al. Identification of methylation related genes from laser capture microdissected colon samples during investigation of adenoma-carcinoma sequence. [Metilációs szabályozás alatt álló gének azonosítása lézerrel kimetszett vastagbéldaganat-sejtekben az adenomacarcinoma sorrend vizsgálata során.] Orv Hetil. 2010; 151: 805-814. [Hungarian]

(Szigeti Krisztina Andrea, Budapest, Szentkirályi u. 46., 1088 e-mail: kri.szigeti@gmail.com)

\section{NOTA}

\section{Új fejlesztés az egészségügyben dolgozók, tanulók részére!}

A magyar nyelvứ szakirodalmi keresőszolgáltatás

\section{Mi a NOTA? \\ Napivizit Orvosi Tudástár Alkalmazás}

\section{Mit tud a NOTA portál?}

Megkönnyíti a magyar nyelvú szakirodalmi források keresését.

Eszköztöl függetlenül, akár okostelefonról, a betegágy mellett állva is használható.

\section{Miben kereshet a NOTA-val?}

Az Akadémiai Kiadó folyóirataiban: Orvosi Hetilap, Magyar Sebészet, Mentálhigiéné és Pszichoszomatika.

Más kiadók magyar nyelvű szakfolyóirataiban: pl. Lege Artis Medicinae, Hypertonia és Nephrologia, Ideggyógyászati Szemle.

A hatályos szakmai irányelvekben.

Magyar nyelvű kérdésekre adott angol nyelvű találatokban, a PubMeden.

\section{nota.hu}
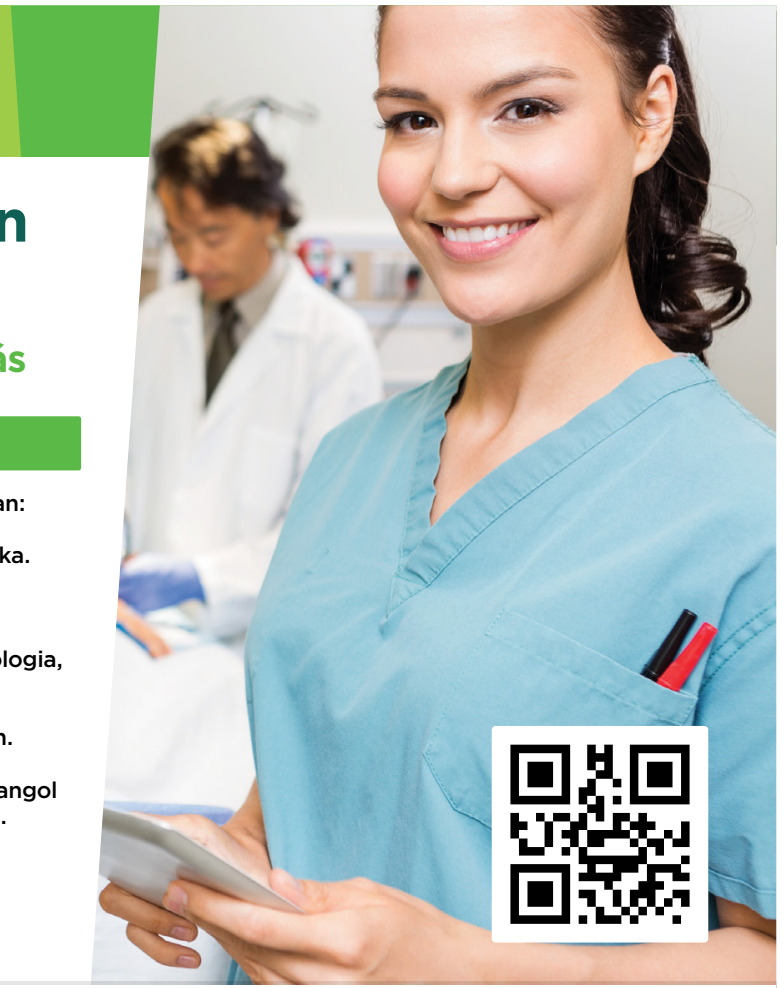

Akadémiai Kiadó

A Wolters Kluwer Csoport tagja

1117 Budapest, Prielle Kornélia u. 21-35. / Telefon: (1) 464-8246 www.akademiai.hu/www.akademiai.com

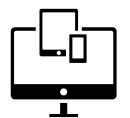

MNOTA

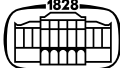

AKADÉMIAI KIADÓ 